Original scientific article

UDC: 613.94(498)"1918/1941"

COBISS.SR-ID 219474956

\title{
Zsuzsa Bokor
}

The Romanian Institute for Research on National Minorities

Gavril Muzicescu 5 Cluj-Napoca 400697, Romania

E-mail: zsbokor@yahoo.com

\section{WOMEN AND EUGENICS \\ IN INTERWAR TRANSYLVANIA}

\begin{abstract}
My paper will focus on the eugenic movement of the Transylvanian medical society in the interwar period. The article attempt to chart the elements in this discourse related to gender and sexuality and will analyze what kinds of transition exist between different gender constructions related to women in this eugenic point of view. Therefore my presentation desires to be the analysis of relations along the oppositions between us and them, feminine and masculine, local and stranger, usual and unusual.
\end{abstract}

Keywords: eugenics, prostitution, venereal diseases, gender identity, feminity, Romania Non MeSH: Transylvania, Cluj, interwar

\section{Introduction}

Central and South-Eastern European institutions of eugenics were a special variety within the great schools of eugenics, for they announced programmes and named problems "that arose locally, from indigenous intellectual and social conditions" [1:8]. Therefore eugenics - in addition to having contained the principles of Galton - did not appear as an independent ideology, but much rather as a social theory, a school subservient to other ideologies.

In Romania, as well as in neighbouring countries, eugenics became a rightwing, nationalist movement only after WWI. This was the case all over Europe, as in the late 1930s and early 1940s the concern with increasing the positive biological 
potential turned into a so-called restrictive eugenics. The researchers of eugenics dealt with the problem of the constant danger threatening the nation and worked on the exclusion and elimination of undesirable elements. The special approach to eugenics in this region was due to the fact that these organizations were concerned about the nation states newly formed after the war, working on the case of a "homogeneous national community", and almost all of them shared the principle that "the state was a nation state and the ethnic majority therein represented the nation" [1:7]. The multicoloured political racisms deriving from a puzzle of eugenics movements were at the same time the cornerstones of a modern nation state model. After WWI, the majority of eugenics experts in Romania lived and worked in Transylvania. Not surprisingly, since the political change that occurred there (Transylvania's detachment from Hungary and its integration into Romania) was a new situation in which this eugenics discourse easily found its place. Though this ideology was concerned about the health of the nation, its initiatives were drawn more to positive eugenics than negative eugenics, like in some Western-European countries.

In my earlier works I analyzed the strategies of building medical institutions around the case of venereal diseases, and how the problem of venereal diseases and prostitution was turned into a national affair. I looked at this problem in a Transylvanian city, Cluj, which was an important location from several points of view: formerly a free royal town, it was a city with strong urban traditions, inhabited by a Hungarian ethnic majority, and a university centre. It was an extremely important centre also from the point of view of eugenics discourse, as it became the stronghold of the school of eugenics after WWI. There is therefore an ethnic, national side to the social historical events in the absence of which it is impossible to understand the local changes of micros-institutions, as, say, the institutions of prostitution. $[2,15]^{1}$

In what follows, I shall not discuss all the aspects of this slide of social history of Cluj, but, starting from my previous local historical researches, I shall summarize some of the representations of gender and sexuality making connection between gender and eugenics in this period. The first part treats the bio-politics of Iuliu Moldovan, a prominent figure of Transylvanian eugenics in the interwar period. In the second part I present the various types of women figures that had an outstanding role in public discourse, in the press and in medical texts, analyzing how flexible the categories of certain women figures are, how easily they move on the axis of respectable-unrespectable, or eugenic-dysgenic, using the moral terms of eugenics.

\section{What it meant to be a eugenics expert in Romania. Iuliu Moldovan's concept of eugenics}

Eugenics was one of the most popular movements among Romanian doctors in the interwar period. The leading figure of Transylvanian institutional changes after WWI and the first Romanian adept of the principles of eugenics was Iuliu Moldovan (1882-1966), medical professor in Cluj. Iuliu Moldovan was born in Transylvania,

1 This paper represents also a short version of the main ideas from my previous work [2]. 
in the family of a Greek Catholic priest of Bogata in Mures County. His childhood experiences largely determined his relation with the Romanians from Transylvania, as he repeatedly confessed in his writings. He studied medicine at the Medical School of Vienna, specializing in epidemiology. He worked in Prague, then Vienna, and served as a surgeon in the Austro-Hungarian army during the World War. He obtained his doctoral diploma in Vienna in 1915 in the field of general pathology. After the war, he returned home and held important positions both in medical institutions and in politics, from head of department to minister. He founded the Department of Bio-politics within the Faculty of Medicine in Cluj. He was the main advocate of eugenics in Romania, and the leader of researches in eugenics. Already in 1924 he published articles on bio-politics and eugenics in various periodicals. He published the works Igiena națiunii (The hygiene of the nation) in 1925, and Biopolitica (Bio-politics) in 1926, and in 1927 started the section on these subjects within the ASTRA, which he also presided between 1932 and 1947. He also founded the journal Buletin Eugenic şi Biopolitic (Bulletin of eugenics and bio-politics) in 1927.

On the very first pages of the Igiena națiunii, Moldovan formulated the major tendencies of eugenics that he considered worthy to follow: "eugenics is exclusively interested in hereditary factors which come down from parents to children, and are not traits given by the physical or social environment," taking a position on Mendel's concept of eugenics. In Moldovan's interpretation the objective was the qualitative improvement of the species, the future generations' protection from illness and "intoxications like venereal diseases and alcoholism", and "to remove from the nation the mentally disabled, the murderers or people who suffer from other diseases". [3:3].

Two basic principles operated in these processes: first, the community (especially national) interests were always above individual interests; and second, the protection of these interests was the responsibility of the state. Eugenics as a modern solution, claims Maria Bucur, was the basis of the discourse which explained social problems in biologized terms. [4:29].

\section{Gender, class, nation and species in the new social hierarchy}

Moldovan's works, especially his study entitled Igiena națiunii is a good indication of how the categories of ethnicity and class are connected to the problem of sexuality, and how the social inequalities constructed difference as a new category. At the same time, this piece of writing also draws closer to the premise that gender is an indispensable category to study social changes, one of the major methodological theses of my paper as well. Gender, ethnicity and class are often superimposed, resulting in hierarchy and social inequalities. The most spectacular example for this is the new social hierarchy, in which the social relations are reordered on the basis of gender, education and biological and ethnical purity, into a new social order of inequalities, which excluded first of all women with irregular sexuality, the mentally disabled people, the various ethnicities (different from Romanian) and religions, and ad absurdum even the middle class as well. 
How was this new social hierarchy envisaged by Moldovan as the model of a new social order, which had to be maintained, in his opinion, by the state? On the top of this order there were healthy Romanian men with high education, usually working in domains far from politics or administration (this was the new "natural elite"). This social stratum - especially for the Romanian representatives of eugenics - was not the well-off middle class. They usually turned against the middle class, the bourgeoisie, the "old elite", because it meant (especially in Transylvania) the stratum of entrepreneurs and officials of different ethnicity (Hungarian, German, Jewish), which was placed at the bottom of the hierarchy, and even considered as a dysgenic ${ }^{2}$ element. The other superior stratum were the peasants, considered by the professionals of eugenics the biological capital of the nation. The Romanian rural society is extremely contradictory in this respect, it was simultaneously the most valuable and most victimized, that is, devalued population.

At the bottom of the hierarchy, near the other ethnicities were those women who did not took on their duties as housewives and mothers honourably, in the interest of the nation. Everybody who was different (in ethnicity, sexual habits, or life conduct) counted as wrong (dysgenic) from the point of view of the nation's eugenics, and could not be part of the healthy body of the nation. ${ }^{3}$ The physicians - just like in $19^{\text {th }}$ century Victorian England - enforced the male society's conceptions on women: the female nervous system and body construction destined women only for the role of mothers and caretakers, as "the doctors considered women the products and prisoners of their reproductive system" [6:335]. This view was most often mirrored in the writings of Constantin Stanca. That the mission of women only related to their home was of course not invented by Romanian eugenics. This was how medicine could make the mothers "instruments of the influence of medicine" and colonize the family [7:135], and this was how the family became "more open to medical supervision and guidance". [7:135]

While Western eugenics primarily envisaged noble, influential people coming from good families with few children, or no children at all [ibid. 14], the Romanian eugenics policy (especially its Transylvanian version) often criticized and attacked this view. Instead, it was much more eager to rely on the peasantry, emphasized its values, and made it its political programme to elevate the peasantry from the backwardness that it supposedly found itself in.

\section{Female figures, female bodies. On gender roles assigned to women}

Since the woman (especially the urban woman) was thought to be prone to aberration, several programmes were elaborated and several institutions were created to handle this problem. As Nira Yuval-Davis explains in her work Gender and Nation,

2 This category also included the mentally disabled, the mentally ill, criminals, epileptics, addicts, the ill (people with tuberculosis, syphilis, leprosy, or other chronic diseases), the blind, the deaf, the physically disabled, the homeless, etc., who were socially inadequate groups according to the western eugenic model and needed to be sterilized [5]

3 A further detailed analysis of the new hierarchy of eugenics in [4:174] 
women's citizenship in these communities is usually of a „dual nature”: „ on the one hand they are included in the general body of citizens, ont he other hand there are always rules, regulations and policies which are specific to them [8:24], and this is especially important to take into account when studying the political implictions of the ways women are constructed as "biological reproducers of 'the nation." [8:24] Ever since the $19^{\text {th }}$ century, in the European society the concept of the national was generally connected to the concept of respectability: it was associated with decency, purity, virtue, modesty, and it was part of the principles of body politics and sexuality of the age [9:2], further increased by opinions on normal and abnormal sexuality [9:10]. In the time of transition the woman became an emphatic object in scientific and everyday debates (women's unruliness, women's hysteria, women's ambitions in contrast with the mother's role, the ideal of the respectable woman). Therefore the transition means at the same time the change of the political circumstances, the permeability of the boundaries between various roles and values, and the new gender constructions resulted from these.

In what follows, I shall review through various examples how flexible the boundaries between respectable and disrespectable, idealized and demonized women were in the years of transition, which conditions led to which kind of roles, and what values the society rendered to these roles. The constant and eternal dichotomy was of course represented by the contrasting image of the demonic woman - respectable woman, within which the poles remained constant, what changed was only the person who occupied one position or another on the two poles. In most cases it was of course the "prostitute" who contrasted with the "respectable gentle woman", the prototype of the mother and the wife, but the place of other women figures was also questionable, such as the house servant, the peasant girl, or other women working in professions considered feminine, such as the manicurist, the confectioner, the cashier, the dancer, the actress.

Interestingly enough, Romanian eugenics treated the deviants, the "criminals" and prostitutes quite moderately, and did not want to exclude them from the nation, as long as their condition was discovered to be due to environmental, and not hereditary factors. In such cases solutions were sought to "reinstall" the undesirable individuals in the society as respectable citizens and mothers. It was the women's sewing workshop of the women's hospital from Cluj founded in December 1919, that offered work for women who "left the wrong way" or wanted to repent. This workshop offered housing and home for these women on the model of Magdalene asylums across Europe, and in exchange it gave them "women's work" to find their way back into society. $[10,11]$ However, it was not a matter of free choice: for some (for instance, women with serious sexual infections, like chronic gonorrhoea) it was compulsory to give up their promiscuous life. There was only one way for them to reintegrate in society: under permanent medical control and as workers in sewing workshops. In these workshops they made underwear, women's fashion items, men's clothes and home textiles for a reasonable price, mostly for state officials and the military. Another "dysgenic" group that attracted special attention besides prostitutes was that of middle class women, and especially the feminists among them were considered dangerous. The middle class woman was dysgenic because of her attraction 
to bespangling, her reduced childbearing intention, and the practice of marrying men of other ethnicity, frequent among these women. But this category was very heterogeneous as well: some women of this class were considered useful elements in this system, they were colleagues and collaborators of the eugenic society.

One of the most changing positions was that of the gentlewoman, who was associated with an extreme spectrum of value judgments, as this figure appears either on the one, or the other of the poles. This figure wasn't a social class category, rather a moral category of the leading and decision-making elite, a representation of feminity. One example of the ideal gentle woman in Romanian public thinking was the middle class woman who ideologically supported the protectors of the nation, and took part in the elaboration of social programmes. Maria Baiulescu, President of the Association of Romanian Women from Transylvania, exposed at a conference in Cluj: women's education must be resolved and workplaces appropriate for the female soul must be established in order for a Romanian woman to be able to provide her nation with adequate virtues.

"A busy intelligent woman - Baiulescu said - may spend some hours also outside her house. Such a marriage will be happier than the one in which the woman, like a feeble puppet, is forced to waste her energy on luxuries and flirting, and on this steep slope to finally reach the fate of Mme Bovary" [12:146]. This excerpt alone shows too how the rhetoric of repression connected morality and sexuality, and interpreted the female figures primarily on this basis. Middle class women taking part in social programmes were those conservative feminists who imagined their activity on the model of pre-war women's associations. The other, the radical line of feminists included other kinds of women, "dangerous for society". For the public discourse of eugenics, the feminists, especially those who seriously took up the fight for women's political and civil rights in the 1920s-1930s, were a danger similar to prostitutes. The fear from female sexuality is stronger in the texts about middle class women, probably because feminist women, who fundamentally transformed the obligations connected to women and reshaped the image on female sexuality and corporeality, also grew out of the middle classes. The gentlewoman, the respectable woman (femeia cinstită) was most often an ideal which represented a Romanian woman who could only outlive her femininity in marriage, a woman living for her nation. The main attribution of this type is seriousness, national consciousness and national responsibility; however, what made this type feminine, was nothing else then her closing up into the private sphere, bearing and raising children. The right-wing conception produced by the specifically Romanian line of the ideology of bio-politics continued thus to regard women as the mirror of the state and the protector of national tradition [9:17].

Another equally important actor of the discourse of the age is the house servant. The image of young peasant girls leaving their village to live and work in a vulnerable position, getting pregnant and expelled from their community, or often killing themselves is well-known from literature. The association of the servant and the prostitute displayed the middle class' fear from women who worked outside the private space of their home. The servant who left behind her provinciality, and cle- 
arly bore the signs of being "mature for urbanization" [13:72] on the boundary of otherness and sameness seemed even more threatening in her unidentifiable being.

The most dangerous figure of this female tableau was the prostitute, because of her otherness and illness (or potentiality for illness). By the end of the 1920s the health care authorities managed to expand the range of people who were singled out for supervision or treatment. Unregistered prostitutes were no longer the only 'dangerous' women in Cluj. Medical attention focused on all prostitutes and women who due to their way of life, work, and so on, might have been forced to prostitute themselves or could have been connected to people working in this area. As Iuliu Moldovan put in 1922:

Morally, every sexually promiscuous woman can be regarded sinful because of her promiscuity. From a hygienic point of view the following sanitation methods are only applied to prostitutes who are considered to be infection foci or may become one because of the lack of adequate protection, irrespective of whether or not their promiscuity is a source of income.[16]

As one can see in this quote, Moldovan brought women from completely different social classes into one group, moreover created the group of prostitutes as a conglomeration for every woman who showed different sexual attitudes. Equally important, he also referred to the prostitute as a nation-threatening enemy because of her illness or disposition for illness.

For a eugenic specialist, the prostitute is dangerous especially because of the venereal diseases she spread. The most important distinctive marks of an ill prostitute are the sunken cheeks and the rashes on the skin. The healthy prostitute also appears through her body: the warning outfit prepared for the "consumer", the heavy makeup, the dyed hair, the conspicuous clothing, the provocative behaviour. The body of the prostitute is a liminal object, the embodiment of an identity at the boundary of the normal and the abnormal, bearing the conflicts of the social space. The representation of the ill Other is in fact a means to maintain the boundaries. The ill prostitute represents physical danger for the citizen (the individual) who sends her to the brothel and regulates her life, but this danger can be easily warded off by well-established (physical) regulating mechanisms (control, hospitalization, separation, the protection of the male body by various prophylactic techniques). However, she is a threat for the nation embraced and represented by the physician, and a symbolic fight must be waged against her. The infection increases this danger, the infection has a symbolic meaning. The woman with dangerous sexuality does not only break the boundaries of health and illness, but further deepens this conflict by her sexuality.

The prostitute was also the object of several contradictory opinions in this period. "The prostitute is a woman whose intellect is low, who lacks moral values, who sells herself in lack of a respectable profession, which she was unable to master because of material or intellectual reasons." - this is how Aurel Voina thought about it even long after the creation of the school of eugenics [14:76]. This is in 
fact one of the most frequently treated subjects in the Romanian programme of eugenics. Representatives of eugenics throughout the world tended to regard sexual deviances not so much as moral weakness but rather as a hereditary issue, leading to the weakening of the ruling species. In the Romanian discourse of eugenics the image of the ideal woman of the new social hierarchy did not necessarily accompany a set of unitary views on prostitutes. These discourses equally talked about the original sinfulness of prostitutes and their social reintegration, seeing (presenting) them in turns as vicious sinners and future mothers and wives. However, both of these mirror in fact the problematic sides of one and the same idealized woman: the one who cannot keep her sexuality under control, and the "respectable" woman. These roles, or in the term of Kobena Mercer, this "burden of representation" [8:45], had an intense effect on the institutional struggles against venereal diseases between the two World Wars. This classification only partly followed the Western discourses of eugenics and the scientific racism that categorically divided the society into two groups: the one (species) healthy, rich and educable, the other vulnerable, weak, poor or not quite rich and uneducable, or born with hereditary dullness [5:XVII].

In my research recognizing the hybrid forms of female figures also turned out some other points. What is then the thing that makes a woman prostitute? This question led to the recognition of the fact that socio-professional categorization can be understood mainly from the inside, from the universe of the social actors, as we cannot work with the existence of the group of prostitutes as an evidence.

\section{Conclusion}

After WWI the city of Cluj had to face significant economical and social changes. One of the basic problems of the public discourse of that era was the mass that could not be controlled or seen through. The economical and social processes were written into basic political changes, as a new power situation was in formation, and Romanians found themselves in the situation of being in majority and holding power and initiative. The new medical power - which followed mainly the ideas of eugenics - declared the reinterpretation of society's basic components, the liquidation of postwar chaos and the clean-up of all remains from the previous political system. An important perspective of my analysis is the exploring how this medical society used the tools of eugenics to explain post-war social changes and how tried to shape different forms of feminity by this kind of discourse. This point of view can lead us to understand the processes of representation in which this power discourse had taken concrete forms.

The controlling power creating, delimiting and releasing "differentiated bodies" proposed different conditions: that of a deadbeat citizen woman, or that of the ill woman, for who the hospital or the sewing workshop was created, etc. To these conditions there had been related different discourse elements, norms and 
judgments, these being present on the public level too, but also being interiorized within individual life stories.

\section{References}

1. Turda M, Weindling PJ. Eugenics, race and nation in Central and Southeast Europe, 1900-1940: A historiographic overview. In: Turda, Marius - Weindling, Paul J (ed.): Blood and homeland: Eugenics and rational nationalism in Central and Southeast Europe, 1900-1940. Central European University Press. Budapest. 2007; 1-20.

2. Bokor Zs. Testtörténetek. A nemzet és a nemi betegségek medikalizálása a két világháború közötti Kolozsváron [Body tales. The nation and the medicalization of the venereal diseases in interwar Cluj]. Cluj. Institutul pentru Studierea Problemelor Minorităților Naționale; 2013.

3. Moldovan I. Eugenia - Igiena națiunei. [Eugenics and the hygiene of the nation]. Buletin eugenic şi biopolitic. 1927; 1(I): 3-4.

4. Bucur M. Eugenie şi modernizare în România interbelică [Eugenics and modernization in interwar Romania]. Polirom. Iaşi; 2005.

5. Chase A. The legacy of malthus. The social costs of the new scientific racism. Univ. Of Illinois Press. Urbana-Chicago-London; 1980.

6. Smith-Rosenberg C, Rosenberg C. The female animal: medical and biological views of woman and her role in nineteenth-century America. The Journal of American History. 1973;2(60):332-356.

7. Lasch C. Az átalakulóban lévő család [Family in the making]. Világtörténet. 1982;1:131-139.

8. Yuval-Davis. N. Gender and Nation. SAGE Publications; 1997.

9. George L. M. Nationalism and sexuality: respectability and abnormal sexuality in modern Europe. H. Fertig; 1985.

10. Dominic S. Spitalul de femei şi ambulatorul policlinic din Cluj în cei cinci ani de funcțiune (1919-1923) [The activity of the Women's Hospital and the Outpatient Unit in Cluj in their five years (1919-1923) ]. Clujul Medical. 1925;3-4(V):60-65.

11. Dominic S. Zece ani de la înființarea spitalului de femei şi ambulatorului policlinic Cluj (1919-1929) [Ten years from the foundation of the Women's Hospital and the Outpatient Unit in Cluj ]. Clujul Medical. 1929;11(IX):535-546.

12. Baiulescu, M. Rolul biopolitic al femeii române [The biopolitic role of the Romanian woman]. Buletin eugenic şi biopolitic. 1927;2(1):140-148.

13. Gyáni G. „Menek Pestre cselédnek”. A budapesti női házicselédek az 1920-as években [The servants in Budapest in the 1920s]. Valóság. 1979;11(XXII):67-76.

14. Voina A. Cum ne apărăm de sifilis. [How do we defend ourselves from syphilis]. Editura Cugetarea. Bucureşti; 1940.

15. Bokor Zs. Girls, doctors and institutions. Revista de antropologie urbană. 2015;5(III):21-26.

16. Instrucțiuni pentru ambulatoarele policlinice.[Instructions for the Outpatient Units] Ordin nr. 10992. Inspectoratul General Sanitar, Cluj, 1922; 5.

Submitted: 9. 11. 2015.

Reviewed: 18. 11. 2015.

Accepted: 21. 11. 2015. 